\title{
Improving Water Productivity and Reducing Nutrient Losses by Controlled Irrigation and Drainage in Paddy Fields
}

\author{
Shikai Gao, Shuangen Yu*, Mei Wang ${ }^{1}$, Jiajia Meng ${ }^{1,2}$, Shuhai Tang², \\ Jihui Ding ${ }^{1}$, Si Li ${ }^{1}$, Zimei Miao ${ }^{3}$
}

${ }^{1}$ Key Laboratory of Efficient Irrigation-Drainage and Agricultural Soil-Water Environment in Southern China, Ministry of Education, College of Water Conservancy and Hydropower Engineering, Hohai University, Nanjing 210098, China

${ }^{2}$ Lianshui Water Conservancy Experiment Station, Huaian Water Resources Bureau, Huaian 223001, China ${ }^{3}$ Research Center of Fluid Machinery and Engineering, Jiangsu University, Zhenjiang 212013, China

Received: 24 July 2017

Accepted: 3 September 2017

\begin{abstract}
Controlled irrigation and drainage (CID) has received considerable attention as a reliable management practice for improving water quality and water productivity in rice production. This study aimed to evaluate the effects of CID on water productivity, nitrogen, and phosphorus losses in paddy fields. Treatments include alternate wetting and drying (AWD; lower limit of irrigation to $-200 \mathrm{~mm}$ and upper limit of ponding water depth after rainfall to $60 \mathrm{~mm}$ ), CID-I (lower limit of irrigation to $-200 \mathrm{~mm}$ and upper limit of ponding water depth after rainfall to $200 \mathrm{~mm}$ ), and CID-II (lower limit of irrigation to -500 $\mathrm{mm}$ and upper limit of ponding water depth after rainfall to $200 \mathrm{~mm}$ ). Results showed that CID reduced irrigation water without a significant impact on grain yields and increased the irrigation water productivity by $14.6-51.5 \%$ compared with AWD. However, the percolation of CID may be increased, especially in a wetting year. The application of CID-II by combining yield with irrigation water productivity could be suitable and beneficial to rice crops. The average total nitrogen (TN) and total phosphorus (TP) concentrations of CID presented similar values or were significantly increased relative to AWD, indicating that the significant decreases in nutrient loads under CID were primarily due to reductions in surface runoff rather than changes in concentration. Ammonium nitrogen $\left(\mathrm{NH}_{4}^{+}-\mathrm{N}\right)$ concentrations were clearly increased after fertilizer application in percolation water. Compared with AWD, the $\mathrm{NH}_{4}^{+}-\mathrm{N}, \mathrm{TN}$, and TP leaching losses of CID-I were increased. The nitrogen and phosphorus leaching losses of CID-II were significantly increased relative to AWD and CID-I because of high nutrient concentrations and severe preferential flow. Therefore, CID potentially increased nitrogen and phosphorus loading to groundwater
\end{abstract}

*e-mail: seyu@hhu.edu.cn 
when the lower limit irrigation was used. The results indicate that the suitable application of CID can save fresh water, reduce nutrient losses, and guarantee rice production.

Keywords: controlled irrigation and drainage, water productivity, yield, nitrogen and phosphorus losses, concentration

\section{Introduction}

Rice (Oryza sativa L.) is the most important staple food in Asia - especially in China [1]. The rice season in southern China coincides with the summer wet season, and average annual precipitation is approximately $500-1,000 \mathrm{~mm}$. Drainage is an important measure to allow timely field operation and protect field rice from waterlogging [2]. Nitrogen $(\mathrm{N})$ and phosphorus $(\mathrm{P})$ loads from unmanaged agricultural non-point sources, such as runoff and leaching from paddy fields, are associated with water body eutrophication of many lakes and streams [3-5]. However, paddy fields as wetlands can achieve the effect of water purification by maintaining proper water level on the surface for a certain number of days after fertilization, pest control, and heavy rain [6-7]. Therefore, it is important to guide the practice of agricultural production by studying the technology of controlled drainage and water-saving irrigation.

Studies demonstrated significant reductions of $\mathrm{N}$ and $\mathrm{P}$ in drainage water discharged from controlled drainage systems because of reduced drainage flow and low concentrations in the shallow groundwater [810]. Wesström and Messing (2007) reported $79 \%$ and $94 \%$ reductions in drain outflows for successive years following controlled drainage implementation [11]. These outflows significantly reduced $\mathrm{N}$ and nitrate nitrogen $\left(\mathrm{NO}_{3}^{-}{ }^{-} \mathrm{N}\right)$ losses. Williams et al. (2015) showed drain flow and $\mathrm{NO}_{3}^{-}-\mathrm{N}$ reductions for variable riser heights of $8-34 \%$ and $8-44 \%$, respectively [8]. Wang et al. (2014) found that TP leaching is low but still exceeded the limit value for eutrophication of water [12]. The decrease in water availability for agriculture threatens irrigated rice water productivity, and the methods for reducing irrigation water demands while maintaining grain yield of rice must be investigated [13]. Alternate wetting and drying (AWD) is widely practiced to reduce the water requirements of rice crops in many areas in Asia $[1,14]$. However, this approach has low rainwater use efficiency - especially when rain occurs during the production cycle. Controlled irrigation and drainage (CID) aims to combine the advantages of controlled drainage and AWD. The basic feature of CID is maintaining a high water depth so that drainage water is reduced during rainy days and irrigated when a certain threshold water table is reached (a certain degree of drought stress is produced when soil moisture content is lower than the saturated moisture content and even field capacity). The practice of CID results in dramatic changes in the soil physical environment, including aerobic and anaerobic transitions [15]. This environment in turn controls microbial processes such as mineralization, nitrification, and denitrification that directly affect $\mathrm{N}$ and $\mathrm{P}$ losses [16]. The desirable $\mathrm{N}$ and P losses in CID may be different from those in the AWD field. A higher water depth under CID conditions is maintained, thereby resulting in an increase in soil moisture, which is conducive to microbial denitrification [17]. Partial submergence can result in the accumulation of ammonium nitrogen $\left(\mathrm{NH}_{4}^{+}-\mathrm{N}\right)$, instability of $\mathrm{NO}_{3}^{-}-\mathrm{N}$, and a lowered $\mathrm{N}$ requirement for organic matter decomposition. Therefore, understanding the $\mathrm{N}$ change processes under CID can greatly facilitate regulating rice paddy $\mathrm{N}$ losses and increasing the availability of $\mathrm{N}$.

Various studies have detected the water productivity and nutrient losses in paddy field under AWD or controlled drainage [14, 18-22]. Few studies have concentrated on the conjunct effects of controlled drainage and AWD in the paddy field. In addition, the capability of CID in improving water productivity and reducing nutrient losses compared with AWD should be confirmed. The current study attempts to evaluate the effects of CID on water productivity, nutrient concentrations, and nutrient loads in a paddy field. Our data might help us assess the potential for CID to mitigate $\mathrm{N}$ and $\mathrm{P}$ loss and explore the suitable application of CID, which can economize on fresh water and guarantee rice production.

\section{Materials and Methods}

\section{Experimental Site and Materials}

Field experiments were conducted in 2015 and 2016 at the Lianshui Water Conservancy Experiment Station (latitude $33^{\circ} 50^{\prime} \mathrm{N}$, longitude $119^{\circ} 16^{\prime} \mathrm{E}$ ) in Jiangsu, China. The experimental site has a humid and subtropical climate with an annual average temperature of $14.4^{\circ} \mathrm{C}$. Data from 1981 to 2010 indicate that Lianshui County has a mean annual rainfall of $979.1 \mathrm{~mm}$. Meteorological parameters were measured by an automated weather station at the experimental site. The soil $(0-30 \mathrm{~cm})$ was loamy clay with a pH of 6.82 , soil organic matter of $2.19 \%$, field capacity of $27.9 \%$, total nitrogen of $0.98 \mathrm{~g} \mathrm{~kg}^{-1}$, and total phosphorus of $1.12 \mathrm{~g} \mathrm{~kg}^{-1}$. Liangyou 9918 (hybrid cultivar) was grown in 2015 (2016). Seedlings were cultivated in a seedbed on 25 May in 2015 (30 May in 2016), and then transplanted at a hill spacing of $0.15 \times 0.22 \mathrm{~m}$ with one seedling per hill on 23 June 2015 (28 June 2016). The soil was harrowed and dry-ploughed and then soaked a day before transplanting. A compound fertilizer $\left(\mathrm{N}: \mathrm{P}_{2} \mathrm{O}_{5}: \mathrm{K}_{2} \mathrm{O}, 15: 15: 15\right)$ was used basally applied at a rate of $900 \mathrm{~kg} \mathrm{ha}^{-1}$ on 23 June 2015 (28 June 2016). Urea (nitrogen content: 46.4\%) was used as the tillering and panicle fertilizer and applied at rates of $100 \mathrm{~kg} \mathrm{ha}^{-1}$ in 20 days after transplanting (DAT) in 
2015 (19DAT in 2016), and of $50 \mathrm{~kg} \mathrm{ha}^{-1}$ in 43DAT in 2015 (39DAT in 2016).

\section{Experimental Design}

The field experiments were performed in a complete randomized block design with three replicates. Plot dimensions were $90 \times 27 \mathrm{~m}$. The ridges were $30 \mathrm{~cm}$ wide at the base and $30 \mathrm{~cm}$ high and covered with a plastic membrane and inserted into the plough layer to a depth of $350 \mathrm{~mm}$. Three treatments were available, namely AWD, CID-I, and CID-II. Water depth was maintained at $30 \mathrm{~mm}$ during the first seven days after transplanting (DAT) for the three irrigation regimes to promote the recovery and establishment of paddy rice seedlings. Then the field water level was allowed to fluctuate between approximately $-200 \mathrm{~mm}$ and $60 \mathrm{~mm}$ in AWD after seven days. In CID, the plots were allowed to be intermittently flooded $(200 \mathrm{~mm})$ after storm water. The irrigation water under CID was applied at a 40-60 mm water level unless the field water level dropped to a certain depth below the topsoil (-200 $\mathrm{mm}$ in CID-I and $-500 \mathrm{~mm}$ in CID-II). The field surface water of the three treatments was drained until no surface water remained nearly 10 days before harvest.

\section{Sample Collection and Measurement}

Three perforated polyvinyl chloride (PVC) pipes (60 $\mathrm{mm}$ diameter) were installed vertically at a depth of 1,800 $\mathrm{mm}$ in each plot to observe field water level. The field water level was observed at 9 o'clock daily with a ruler in the morning. The surface water was collected using $50 \mathrm{~mL}$ syringes (without disturbing the soil and selecting the top surface water randomly); all bottles were rinsed before the appropriate amount of water sample was obtained. Suction cups made of clay materials (20 and $70 \mathrm{~mm}$ in inner diameter and length, respectively) with numerous pores (approximately $0.002 \mathrm{~mm}$ in diameter) were installed vertically at a depth of $600 \mathrm{~mm}$ to collect percolation water before the experiment. The suction cup was embedded in a PVC pipe, thereby allowing the water in the cups to be pumped out. The lower part (porous suction cup zone) of the pipe was surrounded with fine quartz sand, while the upper part (PVC pipe) was surrounded with dried clay powder, thus preventing water to flow from the upper soil layer down to the suction cup.

The volume of percolation water in a paddy field can be calculated as follows [23]:

$$
D_{p}=P+I-R_{f}-E T \pm \Delta S
$$

...where $D_{p}$ is deep percolation ( $\mathrm{mm}$ ) in crop root depth; $P$ is rainfall $(\mathrm{mm})$, with precipitation measured by a tipping bucket rain gauge; $I$ is irrigation water $(\mathrm{mm})$, with irrigation volume estimated by electronic water meters; is surface runoff $(\mathrm{mm})$, with drainage volume measured with runoff collecting barrels; and ET is evapotranspiration $(\mathrm{mm})$, measured with a mini-lysimeter in this experiment.
And the mini-lysimeter $(400 \mathrm{~mm}$ in diameter and $600 \mathrm{~mm}$ in depth) with closed bottom was installed inside the plot to measure evapotranspiration from the field and plants [24]; is the variation of soil water content at crop root depth $(\mathrm{mm})$. During the experimental period, the variation in soil water storage at $0-100 \mathrm{~mm}, 100-300$ $\mathrm{mm}$, and 300-500 $\mathrm{mm}$ soil depth in each treatment was continuously measured when the water depth did not exist at the topsoil.

Grains were air dried for six days before grain yield was determined based on $14 \%$ moisture content. Total water productivity $\left(\mathrm{kg} \mathrm{m}^{-3}\right)$ was calculated as grain yields divided by total water inputs that include rainfall and irrigation. Irrigation water productivity $\left(\mathrm{kg} \mathrm{m}^{-3}\right)$ was calculated as grain yields divided by irrigation water volume. Total nitrogen (TN) concentration was determined with a UV-2800 spectrophotometer after digestion using potassium peroxodisulfate. $\mathrm{NH}_{4}^{+}-\mathrm{N}, \mathrm{NO}_{3}^{-}-\mathrm{N}$, and total phosphorus (TP) in the water samples were analyzed by the indophenol blue method, disulfonic acid phenol method, and ammonium molybdate spectrophotometric method using a UV-2800 spectrophotometer.

\section{Statistical Analysis}

Data were analyzed by one-way ANOVA with least significant difference (LSD) test at the 0.05 probability level. All statistical analyses were performed with SPSS software version 19.0 (SPSS Inc, Chicago, USA).

\section{Results}

\section{Agro-hydrological Conditions}

The field water level of CID and AWD water regimes with rainfall, irrigation, and drainage distribution are presented in Fig. 1. The rainfall from transplanting to harvest was 831 and $561 \mathrm{~mm}$ in 2015 and 2016, respectively. The distribution of precipitation varied in the two years and was more uniform in 2015 than in 2016. The maximum daily precipitation was $181.0 \mathrm{~mm}$ on 31 July 2015 (38DAT) and $92.2 \mathrm{~mm}$ on 30 June 2016 (3DAT). The frequencies of drainage and irrigation were different among different treatments in both years and the lowest frequency was observed under CID-II. The field water level of a paddy field was lower in 2016 than in 2015 because of the relatively dry weather conditions.

Total rainfall, available rainfall, irrigation volume, drainage volume, percolation volume, and total water input during the entire growth period under different treatments are summarized in Table 1 . The available rainfall volume was significantly higher (32.6\% to $41.5 \%)$ under CID treatments than under AWD for both years. Compared with that under AWD, the irrigation volume under CID-I was significantly decreased by $16.1 \%$ in 2015 and $9.7 \%$ in 2016. Compared with that under AWD, the irrigation volume under CID-II was decreased by $37.1 \%$ in 2015 and $26.2 \%$ in 2016. The discrepancy in irrigation 


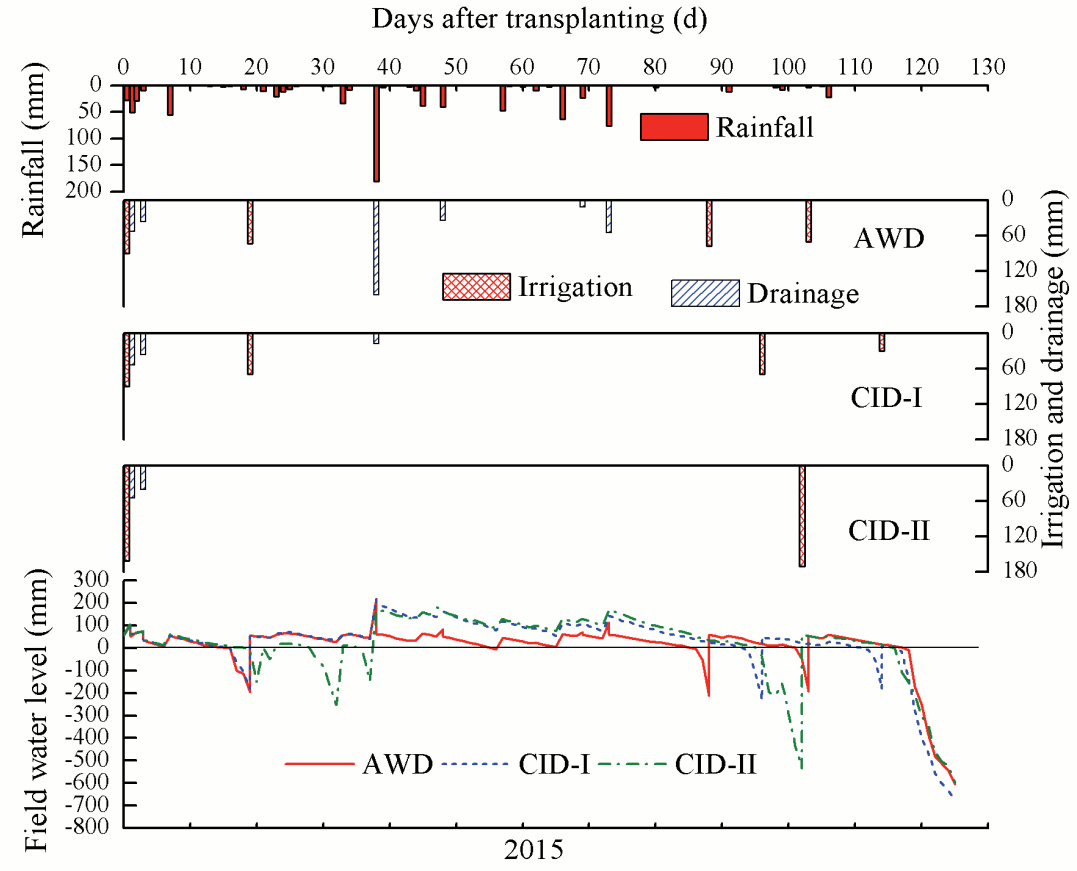

Days after transplanting $(\mathrm{d})$
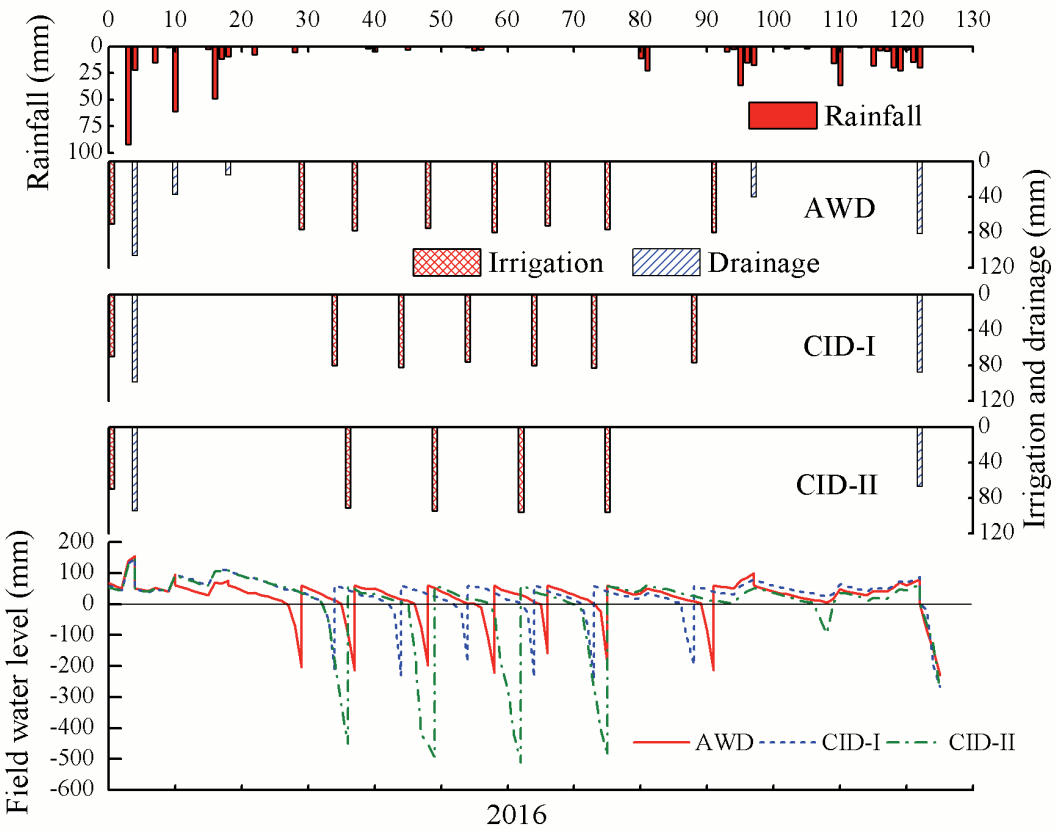

Fig. 1. Daily rainfall, irrigation and drainage, and filled water level from transplanting to harvest of paddy rice under different treatments.

volume for the two years resulted from the distribution of precipitation, which was relatively even and synchronized with the rice water demand in 2015 (Fig. 1). Compared with AWD, the drainage volume was reduced by $33.0 \%$ to $53.3 \%$ in both years. In 2015 the percolation volume was significantly increased by $28.4 \%$ under CID-I and $15.8 \%$ under CID-II relative to AWD. However, the percolation volume in 2016 was decreased by $8.6 \%$ under CID-II relative to AWD, thereby indicating that CID-II may reduce the percolation in the relatively dry weather conditions.

\section{Grain Yield and Water Productivity}

Grain yield and water productivity of paddy rice under different treatments are listed in Table 2. Compared with that under AWD, the grain yield under CID-I was decreased by $2.9 \%$ in 2015 and increased by $3.5 \%$ in 2016. This difference might be explained by the longer flooding period during growth in 2015 (Fig. 1). The grain yield under CID-II was the lowest among the three treatments and decreased by $4.7 \%$ in 2015 and $2.0 \%$ in 2016. Among the different treatments, irrigation water 
Table 1. Total rainfall, available rainfall, irrigation volume, drainage volume, percolation volume, and total water input during the whole growth period under different treatments.

\begin{tabular}{|c|c|c|c|c|c|c|}
\hline Year & Treatments & $\begin{array}{c}\text { Available rainfall } \\
(\mathrm{mm})\end{array}$ & $\begin{array}{c}\text { Irrigation volume } \\
(\mathrm{mm})\end{array}$ & $\begin{array}{c}\text { Drainage volume } \\
(\mathrm{mm})\end{array}$ & $\begin{array}{c}\text { percolation volume } \\
(\mathrm{mm})\end{array}$ & $\begin{array}{c}\text { Total water input } \\
(\mathrm{mm})\end{array}$ \\
\hline \multirow{3}{*}{2015} & AWD & $484^{\mathrm{b}}$ & $310^{\mathrm{a}}$ & $347^{\mathrm{a}}$ & $317^{\mathrm{b}}$ & $1,141^{\mathrm{a}}$ \\
\cline { 2 - 7 } & CID-I & $652^{\mathrm{a}}$ & $260^{\mathrm{b}}$ & $179^{\mathrm{b}}$ & $407^{\mathrm{a}}$ & $1,076^{\mathrm{ab}}$ \\
\cline { 2 - 7 } & CID-II & $669^{\mathrm{a}}$ & $195^{\mathrm{c}}$ & $162^{\mathrm{b}}$ & $367^{\mathrm{a}}$ & $1,026^{\mathrm{b}}$ \\
\hline \multirow{3}{*}{2016} & AWD & $282^{\mathrm{b}}$ & $665^{\mathrm{a}}$ & $279^{\mathrm{a}}$ & $315^{\mathrm{ab}}$ & $1,168^{\mathrm{a}}$ \\
\cline { 2 - 7 } & CID-I & $374^{\mathrm{a}}$ & $587^{\mathrm{b}}$ & $187^{\mathrm{b}}$ & $334^{\mathrm{a}}$ & $1,109^{\mathrm{ab}}$ \\
\cline { 2 - 7 } & CID-II & $399^{\mathrm{a}}$ & $491^{\mathrm{b}}$ & $162^{\mathrm{b}}$ & $288 \mathrm{~b}$ & $1,009^{\mathrm{b}}$ \\
\hline
\end{tabular}

*In the same column and in the same year, means followed by the same letter do not differ significantly at the $5 \%$ level by LSD.

productivity and total water productivity ranged from 1.48 to $4.15 \mathrm{~kg} \mathrm{~m}^{-3}$ and from 0.75 to $0.87 \mathrm{~kg} \mathrm{~m}^{-3}$, respectively. The highest irrigation water productivity and total water productivity were obtained under CIDII, whereas the lowest was obtained under AWD. Compared with AWD, irrigation water productivity was significantly increased by $15.7 \%$ and $14.6 \%$ under CID-I, and $51.5 \%$ and $32.7 \%$ under CID-II in 2015 and 2016, respectively. However, no significant difference was observed in total water productivity between AWD and
CID treatments. Based on the yield and water productivity, the application of CID-II appeared suitable and beneficial to the rice crop.

\section{Change of Nitrogen Concentrations in Surface Water}

The $\mathrm{N}$ fertilizer application was the predominant factor of $\mathrm{NH}_{4}^{+}-\mathrm{N}$ concentrations in surface water as they increased after fertilizer application both in AWD
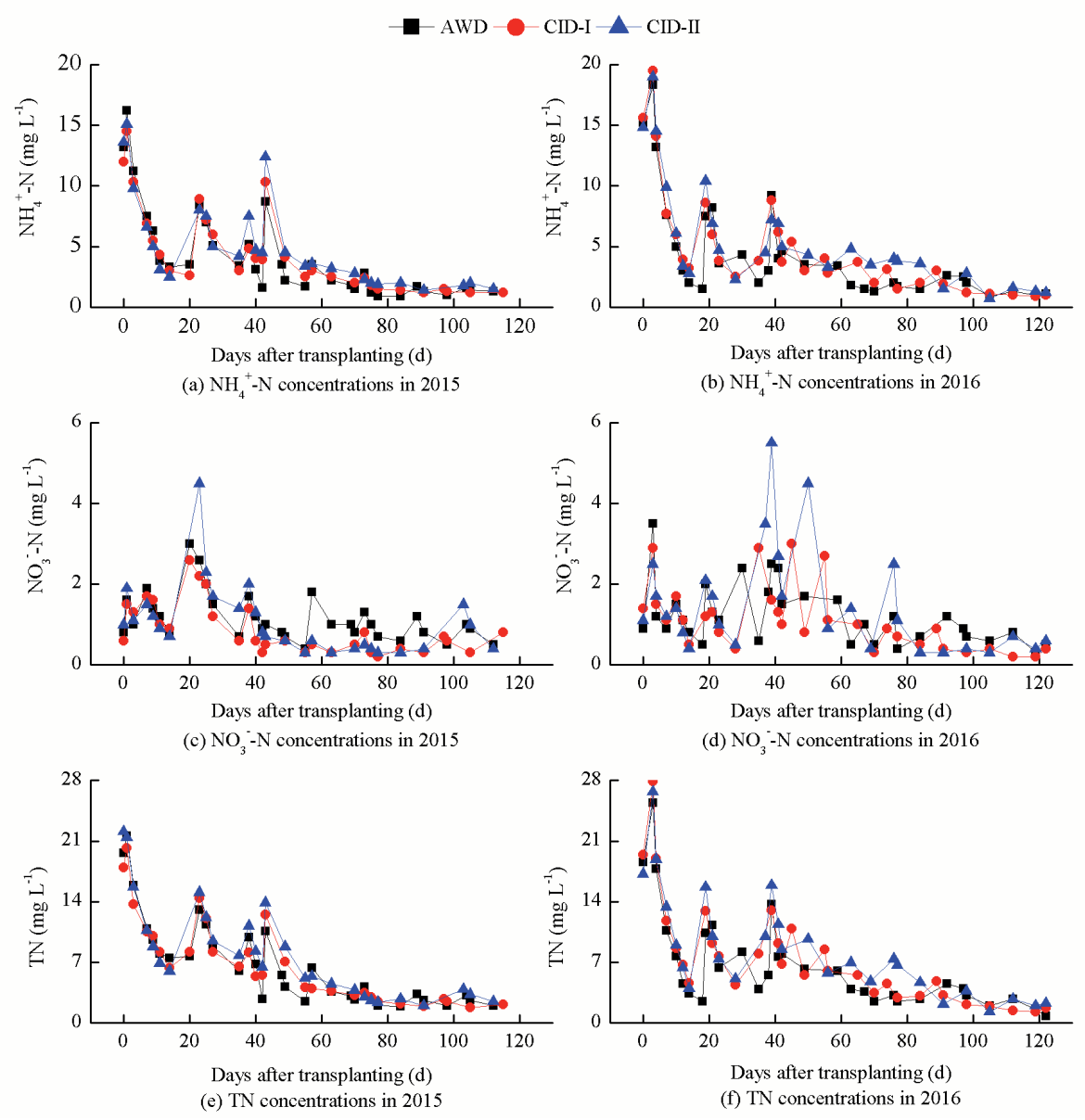

Fig. 2. Change of nitrogen concentrations in surface water under different treatments in 2015 and 2016. 
Table 2. Grain yield and water productivity of paddy rice under different treatments.

\begin{tabular}{|c|c|c|c|c|}
\hline \multirow{3}{*}{ Year } & Treatments & $\begin{array}{c}\text { Grain } \\
\text { yield } \\
\left(\mathrm{kg} \mathrm{ha}^{-1}\right)\end{array}$ & $\begin{array}{c}\text { Irrigation } \\
\text { water } \\
\text { productivity } \\
\left(\mathrm{kg} \mathrm{m}^{-3}\right)\end{array}$ & $\begin{array}{c}\text { Total water } \\
\text { productivity } \\
\left(\mathrm{kg} \mathrm{m}^{-3}\right)\end{array}$ \\
\hline \multirow{3}{*}{2015} & AWD & $8501^{\mathrm{a}}$ & $2.74^{\mathrm{c}}$ & $0.75^{\mathrm{a}}$ \\
\cline { 2 - 5 } & CID-I & $8252^{\mathrm{a}}$ & $3.17^{\mathrm{b}}$ & $0.76^{\mathrm{a}}$ \\
\cline { 2 - 5 } 2016 & CID-II & $8101^{\mathrm{a}}$ & $4.15^{\mathrm{a}}$ & $0.79 \mathrm{a}$ \\
\hline \multirow{3}{*}{} & AWD & $9008^{\mathrm{a}}$ & $1.48^{\mathrm{c}}$ & $0.77^{\mathrm{a}}$ \\
\cline { 2 - 5 } & CID-I & $9319^{\mathrm{a}}$ & $1.70^{\mathrm{b}}$ & $0.84^{\mathrm{a}}$ \\
\cline { 2 - 5 } & CID-II & $8824^{\mathrm{a}}$ & $1.97^{\mathrm{a}}$ & $0.87^{\mathrm{a}}$ \\
\hline
\end{tabular}

*In the same column and in the same year, means followed by the same letter do not differ significantly at the $5 \%$ level by LSD.

and CID paddy field plots (Figs 2a-b). In the CID and AWD treatments, the $\mathrm{NH}_{4}^{+}-\mathrm{N}$ concentrations fluctuated severely in surface water during the vegetative stage. After panicle fertilization, the $\mathrm{NH}_{4}^{+}-\mathrm{N}$ concentrations resulted in a gradual decline until rice harvesting in both years. However, the $\mathrm{NH}_{4}^{+}-\mathrm{N}$ concentrations in CID-II reached $7.50 \mathrm{mg} \mathrm{L}^{-1}$ (38DAT) after a rainstorm in 2016.
The average $\mathrm{NH}_{4}^{+}-\mathrm{N}$ concentrations in surface water were 4.49 and $4.87 \mathrm{mg} \mathrm{L}^{-1}$ under CID-I, and 5.07 and $5.33 \mathrm{mg} \mathrm{L}^{-1}$ under CID-II in 2015 and 2016, respectively. Compared with AWD, the average $\mathrm{NH}_{4}^{+}-\mathrm{N}$ concentrations in surface water were increased by $7.4 \%$ and $11.1 \%$ under CID-I, and $21.2 \%$ and $26.1 \%$ under CID-II in 2015 and 2016, respectively.

The $\mathrm{NO}_{3}^{-}-\mathrm{N}$ concentrations in surface water under different treatments are shown in Figs 2(c-d). In 2015 the maximum $\mathrm{NO}_{3}^{-}-\mathrm{N}$ concentration under CID-II was significantly higher than that under AWD and CID-I because of the application of $\mathrm{N}$ fertilizer after drought. The $\mathrm{NO}_{3}^{-}-\mathrm{N}$ concentrations in AWD sharply increased from $0.30 \mathrm{mg} \mathrm{L}^{-1}$ (55DAT) to $1.82 \mathrm{mg} \mathrm{L}^{-1}$ (57DAT), but the $\mathrm{NO}_{3}^{-}-\mathrm{N}$ concentrations in CID treatments were not clearly changed. In $2016 \mathrm{NO}_{3}^{-}-\mathrm{N}$ concentrations fluctuated severely in surface water compared to 2015. This is because the paddy field experienced more wetting and drying cycles in 2016 than that in 2015, and promoting the nitrification of $\mathrm{NH}_{4}^{+}-\mathrm{N}$. The average $\mathrm{NO}_{3}^{-}-\mathrm{N}$ concentrations in surface water for CID-I were 0.89 and $1.11 \mathrm{mg} \mathrm{L}^{-1}$ in 2015 and 2016, decreasing $23.6 \%$ and $7.7 \%$ compared to AWD. The average $\mathrm{NO}_{3}^{-}-\mathrm{N}$ concentrations in surface water for CID-II were $1.07 \mathrm{mg} \mathrm{L}^{-1}$ in 2015 and $1.49 \mathrm{mg} \mathrm{L}^{-1}$ in 2016, decreasing by $7.6 \%$ in 2015 and increasing by $23.2 \%$ in 2016 compared to AWD.

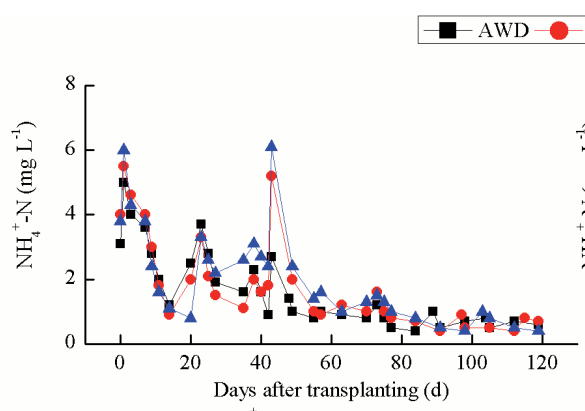

(a) $\mathrm{NH}_{4}^{+}-\mathrm{N}$ concentrations in 2015
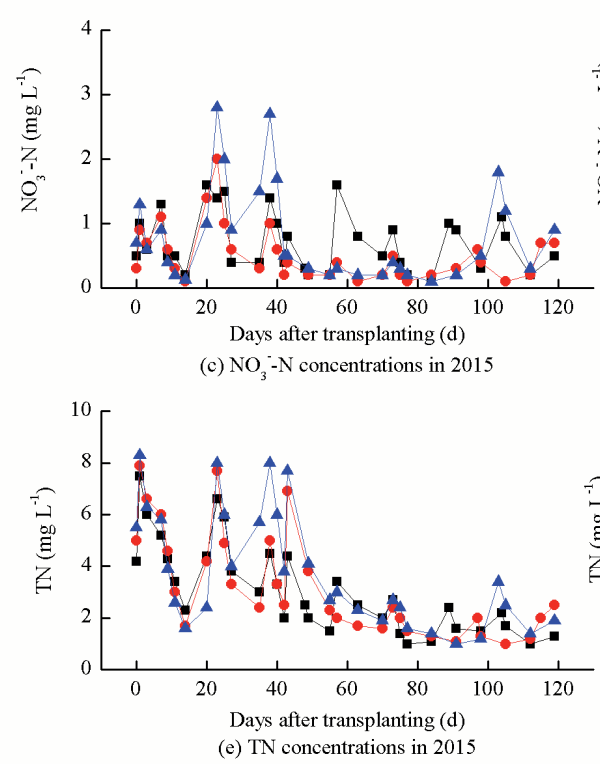

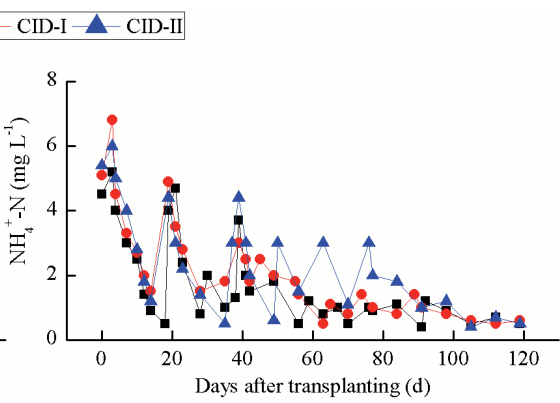

(b) $\mathrm{NH}_{4}^{+}-\mathrm{N}$ concentrations in 2016

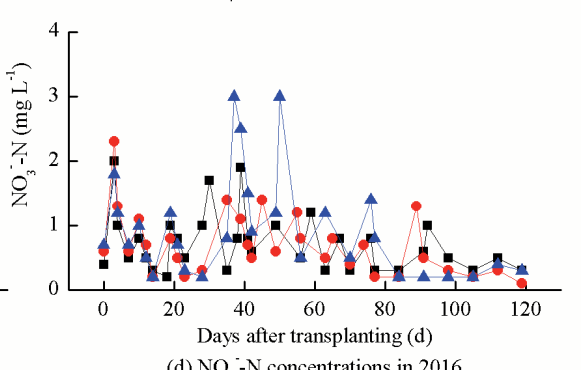

(d) $\mathrm{NO}_{3}-\mathrm{N}$ concentrations in 2016

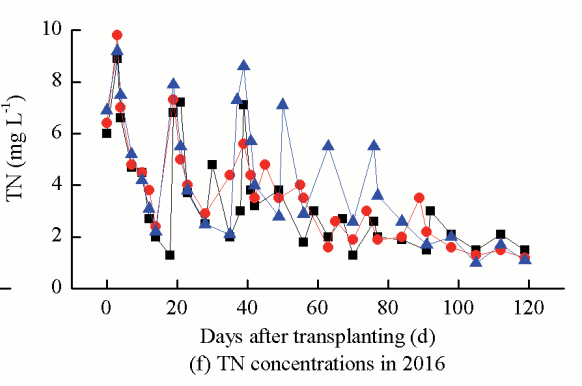

Fig. 3. Change of nitrogen (N) concentrations in percolation water under different treatments in 2015 and 2016. 


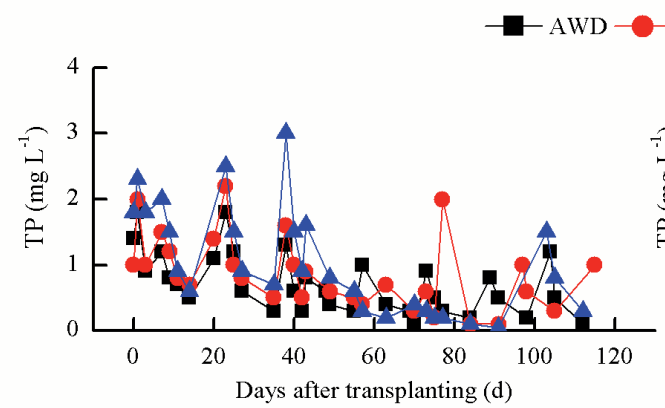

(a) $\mathrm{TP}$ concentrations in surface water in 2015

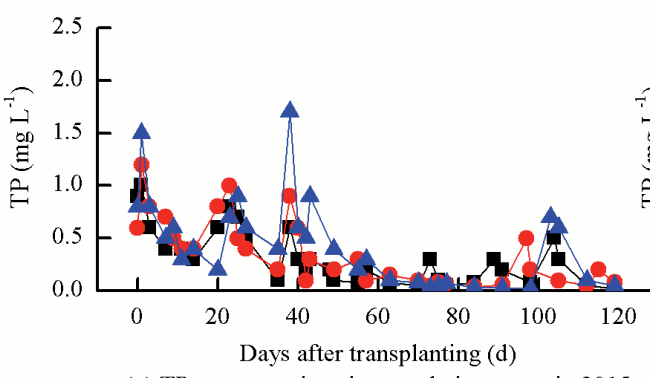

(c) TP concentrations in percolation water in 2015

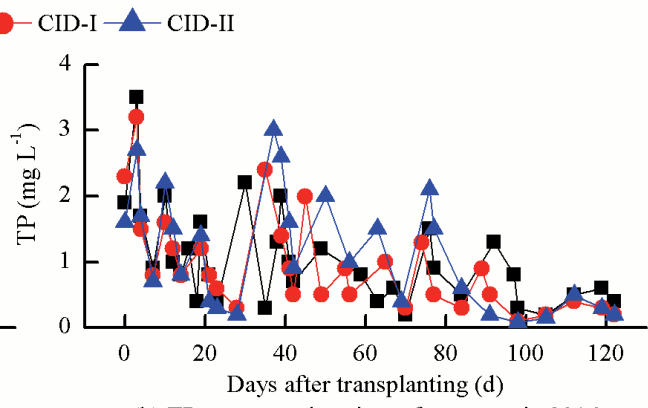

(b) TP concentrations in surface water in 2016

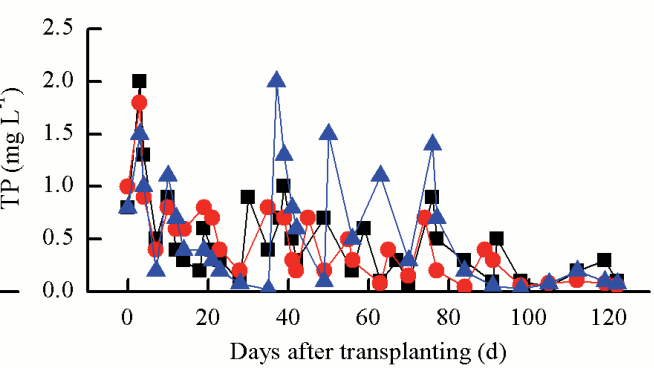

(d) TP concentrations in percolation water in 2016

Fig. 4. The change of total phosphorus (TP) concentrations in paddy water under different treatment in 2015 and 2016.

The TN concentrations varied in the same pattern as $\mathrm{NH}_{4}^{+}-\mathrm{N}$ concentrations in surface water, and were mainly affected by fertilization and rainstorm (Figs 2e-f). The average TN concentrations in surface water were 7.07 and $7.61 \mathrm{mg} \mathrm{L}^{-1}$ under CID-I, and 8.08 and $8.57 \mathrm{mg} \mathrm{L}^{-1}$ under CID-II in 2015 and 2016, respectively. Compared with AWD, the average TN concentrations in surface water were increased by $3.8 \%$ and $13.2 \%$ under CID-I, and by $18.6 \%$ and $27.5 \%$ under CID-II in 2015 and 2016, respectively.

\section{Change of Nitrogen Concentrations in Percolation Water}

The change of $\mathrm{NH}_{4}^{+}-\mathrm{N}$ concentrations in percolation water were mainly affected by not only fertilization and rainstorms, but also irrigation (Figs 3a-b). The $\mathrm{NH}_{4}{ }^{+} \mathrm{N}$ concentrations after panicle fertilization peaked at $5.23 \mathrm{mg}$ $\mathrm{L}^{-1}$ (43DAT) under CID-I and $6.10 \mathrm{mg} \mathrm{L}^{-1}$ (43DAT) under CID-II in 2015. However, the $\mathrm{NH}_{4}^{+}-\mathrm{N}$ concentrations in AWD reached $4.70 \mathrm{mg} \mathrm{L}^{-1}$ (43DAT). In 2016 several peaked values $\left(50,63\right.$, and 76DAT) of the $\mathrm{NH}_{4}{ }^{+} \mathrm{N}$ concentrations under CID-II were observed in the middle and late stages. The average $\mathrm{NH}_{4}^{+}-\mathrm{N}$ concentrations in percolation water were 1.84 and $2.13 \mathrm{mg} \mathrm{L}^{-1}$ under CID-I and 2.09 and $2.41 \mathrm{mg} \mathrm{L}^{-1}$ under CID-II in 2015 and 2016, respectively. Compared with AWD, the average $\mathrm{NH}_{4}{ }^{+} \mathrm{N}$ concentrations in percolation water were increased by 9.7\% and $20.1 \%$ under CID-I and increased by $24.5 \%$ and $36.2 \%$ under CID-II in 2015 and 2016, respectively.

The $\mathrm{NO}_{3}^{-}-\mathrm{N}$ concentrations in percolation water were severely influenced by water management (Figs 3c-d). The $\mathrm{NO}_{3}^{-}-\mathrm{N}$ concentrations under CID-II fluctuated severely in percolation water compared to CID-I and AWD in
2015 and 2016. The average $\mathrm{NO}_{3}^{-}-\mathrm{N}$ concentrations in percolation water for CID-I were 0.52 and $0.70 \mathrm{mg} \mathrm{L}^{-1}$ in 2015 and 2016, respectively, decreasing by $27.2 \%$ and $2.5 \%$ compared with AWD. The average $\mathrm{NO}_{3}^{-}-\mathrm{N}$ concentrations in percolation water for CID-II were 0.80 and $0.94 \mathrm{mg} \mathrm{L}^{-1}$ in 2015 and 2016, respectively, increasing by $12.9 \%$ and $30.5 \%$ compared to AWD.

The TN concentrations varied similarly to $\mathrm{NH}_{4}^{+}-\mathrm{N}$ concentrations in percolation water (Figs 3e-f). The average $\mathrm{TN}$ concentrations in percolation water were 3.27 and $3.74 \mathrm{mg} \mathrm{L}^{-1}$ under CID-I in 2015 and 2016, respectively, and 3.84 and $4.34 \mathrm{mg} \mathrm{L}^{-1}$ under CID-II in 2015 and 2016, respectively. Compared with AWD, the average TN concentrations in percolation water were increased by $5.2 \%$ and $8.6 \%$ under CID-I and $23.6 \%$ and $26.0 \%$ under CID-II in 2015 and 2016, respectively.

\section{Change of Total Phosphorus Concentrations in Paddy Water}

The TP concentrations in paddy water under the different treatments are presented in Fig. 4. The TP concentrations increased in paddy water after fertilizer application. The TP concentrations fluctuated severely in paddy water in 2016 as compared to 2015 . The average TP concentrations in surface water for CID-I were 0.88 and $0.95 \mathrm{mg} \mathrm{L}^{-1}$ in 2015 and 2016, respectively, increasing by $23.5 \%$ and decreasing by $7.7 \%$ compared to AWD. The average TP concentrations in surface water for CID-II were 1.04 and $1.15 \mathrm{mg} \mathrm{L}^{-1}$ in 2015 and 2016, respectively, increasing by $46.1 \%$ and $11.7 \%$ compared to AWD. The average TP concentrations in percolation water for CID-I were 0.37 and $0.46 \mathrm{mg} \mathrm{L}^{-1}$ in 2015 and 2016, respectively, increasing by $10.6 \%$ and decreasing by $6.9 \%$ compared 
Table 3. Nitrogen and phosphorus losses under different treatments.

\begin{tabular}{|c|c|c|c|c|c|c|c|c|c|}
\hline \multirow[b]{2}{*}{ Year } & \multirow[b]{2}{*}{ Treatments } & \multicolumn{4}{|c|}{ Runoff losses } & \multicolumn{4}{|c|}{ Leaching losses } \\
\hline & & $\begin{array}{c}\mathrm{NH}_{4}^{+}-\mathrm{N} \\
\left(\mathrm{kg} \mathrm{ha}^{-1}\right)\end{array}$ & $\begin{array}{l}\mathrm{NO}_{3}^{-}-\mathrm{N} \\
\left(\mathrm{kg} \mathrm{ha}^{-1}\right)\end{array}$ & $\begin{array}{c}\mathrm{TN} \\
\left(\mathrm{kg} \mathrm{ha}^{-1}\right)\end{array}$ & $\begin{array}{c}\mathrm{TP} \\
\left(\mathrm{kg} \mathrm{ha}^{-1}\right)\end{array}$ & $\begin{array}{l}\mathrm{NH}_{4}^{+}-\mathrm{N} \\
\left(\mathrm{kg} \mathrm{ha}^{-1}\right)\end{array}$ & $\begin{array}{c}\mathrm{NO}_{3}-\mathrm{N} \\
\left(\mathrm{kg} \mathrm{ha}^{-1}\right)\end{array}$ & $\begin{array}{c}\mathrm{TN} \\
\left(\mathrm{kg} \mathrm{ha}^{-1}\right)\end{array}$ & $\begin{array}{c}\text { TP } \\
\left(\mathrm{kg} \mathrm{ha}^{-1}\right)\end{array}$ \\
\hline \multirow{3}{*}{2015} & AWD & $24.36^{\mathrm{a}}$ & $5.38^{\mathrm{a}}$ & $38.46^{\mathrm{a}}$ & $4.17^{\mathrm{a}}$ & $6.12^{\mathrm{b}}$ & $2.79^{\mathrm{b}}$ & $12.82^{\mathrm{b}}$ & $1.33^{\mathrm{c}}$ \\
\hline & CID-I & $12.51^{\mathrm{b}}$ & $1.54^{\mathrm{b}}$ & $17.44^{b}$ & $1.74^{\mathrm{b}}$ & $7.96^{\mathrm{a}}$ & $2.56^{\mathrm{b}}$ & $16.92^{\mathrm{a}}$ & $1.67^{\mathrm{b}}$ \\
\hline & CID-II & $12.23^{\mathrm{b}}$ & $1.49^{\mathrm{b}}$ & $18.05^{b}$ & $1.99^{\mathrm{b}}$ & $8.57^{\mathrm{a}}$ & $3.82^{\mathrm{a}}$ & $17.81^{\mathrm{a}}$ & $2.02^{\mathrm{a}}$ \\
\hline \multirow{3}{*}{2016} & AWD & $18.02^{\mathrm{a}}$ & $2.70^{\mathrm{a}}$ & $24.39^{\mathrm{a}}$ & $3.27^{\mathrm{a}}$ & $7.37^{\mathrm{b}}$ & $3.57^{\mathrm{b}}$ & $13.44^{\mathrm{b}}$ & $1.60^{\mathrm{b}}$ \\
\hline & CID-I & $15.83^{\mathrm{b}}$ & $1.84^{\mathrm{b}}$ & $21.30^{\mathrm{b}}$ & $1.66^{\mathrm{b}}$ & $7.98^{\mathrm{b}}$ & $3.29^{\mathrm{b}}$ & $14.51^{\mathrm{b}}$ & $1.71^{\mathrm{b}}$ \\
\hline & CID-II & $14.58^{\mathrm{b}}$ & $2.02^{\mathrm{b}}$ & $19.50^{\mathrm{b}}$ & $1.61^{\mathrm{b}}$ & $8.99^{\mathrm{a}}$ & $4.55^{\mathrm{a}}$ & $16.73^{\mathrm{a}}$ & $2.23^{\mathrm{a}}$ \\
\hline
\end{tabular}

*In the same column and in the same year, means followed by the same letter do not differ significantly at the 5\% level by LSD.

to AWD. The average TP concentrations in percolation water for CID-II were 0.46 and $0.59 \mathrm{mg} \mathrm{L}^{-1}$ in 2015 and 2016 , respectively, increasing by $38.5 \%$ and $21.0 \%$ compared to AWD.

\section{Nitrogen and Phosphorus Loss}

The $\mathrm{N}$ and $\mathrm{P}$ losses under the different treatments are displayed in Table 3. Similar to surface water, $\mathrm{NH}_{4}^{+}-\mathrm{N}$ was the major component of $\mathrm{N}$ in runoff water. The $\mathrm{NH}_{4}^{+}-\mathrm{N}$, $\mathrm{NO}_{3}{ }^{-} \mathrm{N}$, and $\mathrm{TN}$ runoff losses were significantly higher under AWD than under CID-I and CID-II. Compared with AWD, the TN runoff losses were reduced by $54.7 \%$ and $12.7 \%$ under CID-I and $53.1 \%$ and $20.0 \%$ under CIDII in 2015 and 2016, respectively. However, the differences in $\mathrm{NH}_{4}^{+}-\mathrm{N}, \mathrm{NO}_{3}^{-}-\mathrm{N}$, and TN runoff losses between CID-I and CID-II were insignificant. Compared with AWD, the TP runoff losses were significantly reduced by $58.3 \%$ and $49.2 \%$ under CID-I and 52.3\% and 50.8\% under CID-II in 2015 and 2016, respectively.

The leaching losses of $\mathrm{NH}_{4}^{+}-\mathrm{N}$ were higher under CID-I and CID-II than under AWD in both years. The leaching losses of $\mathrm{NO}_{3}^{-}$-N were significantly higher under CIDII than under AWD and CID-I in both years. Compared with AWD, the TN leaching losses were significantly reduced by $32.0 \%$ and $8.0 \%$ under CID-I and $38.9 \%$ and $24.5 \%$ under CID-II in 2015 and 2016, respectively. The difference of the TN leaching losses between CID-I and CID-II was significant in 2016. Compared with AWD, the TP leaching losses were increased by $25.6 \%$ and $6.9 \%$ under CID-I and 51.9\% and 39.4\% under CID-II in 2015 and 2016, respectively. The difference of TP leaching losses was insignificant between CID-I and AWD in 2016. However, the difference of the TP leaching losses between CID-I and CID-II was significant.

\section{Discussion}

AWD is considered an effective water-saving technology in rice production [1, 14]. However, low ponding rainfall depth under AWD is not favorable to the use of rainfall [1, 18]. CID provides a similar or even lower limit of irrigation and higher excess water storage depth than AWD. If ponding water depth after rainstorms in the CID regime was controlled properly, then the plant water status was not adversely affected during the drying period. Such a CID not only saves water, but also potentially maintains or increases grain yield [13]. Our study found that the grain yield under CID-I decreased by $2.9 \%$ in 2015 and increased by $3.5 \%$ in 2016 at a threshold level of $200 \mathrm{~mm}$ after rainstorms (Table 2). Moreover, increasing the lower limit of irrigation to a field water level of -250 $\mathrm{mm}$ and even deeper may be possible for CID. Lampayan et al. (2015) reported that comparable yields are obtained at the threshold of $300 \mathrm{~mm}$ below the topsoil [14]. This study found that the grain yield under CID-II decreased by $4.7 \%$ in 2015 and $2.0 \%$ in 2016 compared to AWD (Table 2). Therefore, CID significantly decreased the lower limit of irrigation and increased ponded water depth relative to AWD and, as a consequence, the drainage and irrigation volumes were clearly decreased - especially in wetting years (Table 1). Similar results were observed in previous findings $[15,25]$. The success of implementation of AWD to decrease water inputs is mostly attributed to reduced seepage and percolation [16]. However, the percolation of CID was significantly increased in 2015 because of extensive flooding and high ponding water depth. The low water productivity for irrigated rice is generally caused by a variety of water losses (evaporation, transpiration, percolation, seepage, and surface runoff); these factors are critical to water productivity in rice production [2627]. The slight differences of rice yields between AWD and CID also contributed to the high variation of water productivity since the CID largely decreased irrigation water. In addition, comparable yields were also achieved under CID-I and CID-II (Table 2).

Many studies have suggested that $\mathrm{NH}_{4}^{+}-\mathrm{N}$ is the stable component of $\mathrm{N}$ in paddy water, and $\mathrm{NH}_{4}^{+}-\mathrm{N}$ is the dominant form of $\mathrm{N}$ runoff [6, 28-29]. Furthermore, $\mathrm{N}$ inputs can stimulate the dissolution of insoluble phosphates in a paddy field [23]. Similar results were also found in the present study. In general, the long-term flooding and high groundwater table $(<400 \mathrm{~mm}$ below 
ground) of paddy fields resulting in nitrification is limited and denitrification is intensive [16]. Meanwhile, flooding condition creates anaerobic conditions with the reduction of $\mathrm{Fe}^{3+}$ to $\mathrm{Fe}^{2+}$, thereby increasing the release of $\mathrm{P}$ into the soil solution [30]. Therefore, the average $\mathrm{NH}_{4}^{+}-\mathrm{N}$ and TP concentrations under CID in surface water were higher than that under AWD. Water stress can inhibit microbial activity by decreasing the intracellular water potential and reducing the hydration and activity of enzymes in soil [31], thereby resulting in the accumulation of inorganic $\mathrm{N}$ under severe drought conditions. Re-flooding a dry soil promotes $\mathrm{N}$ mineralization and nitrification $[2,16]$. The particles in the topsoil are disturbed by irrigation and rainfall - especially in severe drought conditions, thereby inducing the release and suspension of $\mathrm{N}$ and $\mathrm{P}$. As a result, the CID-II achieved the highest average $\mathrm{NH}_{4}^{+}-\mathrm{N}$, $\mathrm{TN}$, and TP concentrations in surface water among three treatments. Due to the frequencies of nitrificationdenitrification caused by the drying and re-flooding of the CID-II as strengthened in drying years, the average $\mathrm{NO}_{3}^{-}-\mathrm{N}$ concentrations of CID-II were significantly higher than AWD in 2016. Therefore, the TN and TP runoff losses must be considered thoroughly when the occurrence of rainstorms, alternate drought flooding stress, and optimum drainage time should be selected according to the changes in $\mathrm{N}$ and $\mathrm{P}$ concentrations. Moreover, the runoff losses of TN and TP in a paddy field are not only associated with TN and TP concentrations but also related to runoff volume [32]. Thus the runoff losses of TN and TP under CID treatments were significantly reduced relative to AWD (Table 3 ).

$\mathrm{N}$ leaching is affected by soil properties, water management, and crop growth. Generally, the $\mathrm{NH}_{4}^{+}-\mathrm{N}$ migration distance in soil is very short. Large proportions of $\mathrm{NH}_{4}^{+}-\mathrm{N}$ in the percolation water from paddy fields comes from the slow mineralization and decomposition of organic $\mathrm{N}$ in the subsoil rather than the slow migration of $\mathrm{NH}_{4}^{+}-\mathrm{N}$ from fertilizers $[23,33]$. However, the current study found that the $\mathrm{NH}_{4}^{+}-\mathrm{N}$ concentrations are clearly increased after fertilizer application in percolation water. This may be due to high percolation and soil cracks of CID that accelerate the transportation of $\mathrm{NH}_{4}^{+}-\mathrm{N}$. The nitrification process is very oxygen demanding [2]. The nitrification was restrained in CID-I because of the high ponding water depth. Thus, the concentrations of $\mathrm{NO}_{3}^{-}-\mathrm{N}$ in CID-I were reduced compared to AWD, and the leaching losses of $\mathrm{NO}_{3}^{-}-\mathrm{N}$ were not significantly different in AWD and CID-I. By contrast, the $\mathrm{NH}_{4}^{+}-\mathrm{N}$ and TN concentrations in CID-I were increased compared to AWD, and the $\mathrm{NH}_{4}^{+}-\mathrm{N}$ and $\mathrm{TN}$ leaching losses were also increased. The difference of $\mathrm{NH}_{4}^{+}-\mathrm{N}$ and $\mathrm{TN}$ leaching losses between CID-I and AWD was significant in the wetting year (2015) because of a significant increase in percolation water volume. Soil cracks formed in paddy fields under drought stress may be the main routes of preferential flow, which can improve the velocity of $\mathrm{N}$ and $P$ transport to the subsoil and groundwater $[12,34]$. The aerobic environment of CID-II is favorable for nitrification in which $\mathrm{NH}_{4}^{+}-\mathrm{N}$ was transformed into $\mathrm{NO}_{3}^{-}-\mathrm{N}$ and increases the concentrations of $\mathrm{NO}_{3}^{-}-\mathrm{N}$. Therefore, CIDII obtained the highest average $\mathrm{NH}_{4}^{+}-\mathrm{N}, \mathrm{NO}_{3}{ }^{-}-\mathrm{N}$, and TN concentrations among the three treatments. Tan et al. (2013) reported that the $\mathrm{N}$ losses in the first three days after re-watering are significantly increased under alternate drying and flooding conditions relative to continuous flooding [16]. Additionally, the cracks may be penetrated under CID-II through the plow pan that existed at 150-250 $\mathrm{mm}$ [34]. As a result, the $\mathrm{N}$ leaching losses in CID-II were significantly increased relative to AWD. Soils generally have a strong adsorption capacity of $\mathrm{P}$ in paddy fields, and thus P leaching can be ignored [12]. The threshold values of eutrophication induced by $\mathrm{P}$ in paddy fields water are approximately $0.05 \mathrm{mg} \mathrm{L}^{-1}$ [35]. However, the average TP concentrations in the present study clearly exceeded the threshold value, and $\mathrm{P}$ leaching is the main reason for water eutrophication. Thus, effective measures should be taken to restrain high TP concentrations in percolation water in the future - especially for CID-II.

\section{Conclusions}

In conclusion, CID provides both a lower limit of irrigation and greater excess water storage depth compared to AWD. Therefore, the amount of surface runoff decreased to some extent when confronted with concentrated rainfall or extreme rainstorm events, thereby resulting in high available rainfall. Under CID, farmers can adopt a lower limit of irrigation to $500 \mathrm{~mm}$ and a threshold level of $200 \mathrm{~mm}$ after a rainstorm. The irrigation water productivity of CID increased by 14.6$51.5 \%$ compared with AWD with the marginal reductions in grain yield. However, due to long-term flooding and the high ponding water depth, the percolation of CID may be increased because of extensive flooding and high ponding water depth. Based on the yield and water productivity, the application of CID-II can be suitable and beneficial to rice crops. The results of this study also showed that the main form of $\mathrm{N}$ runoff losses and leaching losses was $\mathrm{NH}_{4}^{+}-\mathrm{N}$. The average $\mathrm{NH}_{4}^{+}-\mathrm{N}$ and TP concentrations under CID in surface water were higher than that under AWD. The runoff losses of TN and TP under CID treatments were significantly reduced relative to AWD, but no significant difference was observed between CID-I and CID-II. The $\mathrm{N}$ and $\mathrm{P}$ leaching losses in CID-II were significantly increased relative to AWD. Therefore, CID potentially increased the $\mathrm{N}$ and $\mathrm{P}$ loading to the groundwater when the lower limit of irrigation was used. This should be considered in the strategic and tactical decision process for wide adoption of CID.

\section{Acknowledgements}

This work was funded by the National Natural Science Foundation of China (Nos. 51479063, 41401628, and 51679108) and supported by the Fundamental Research Funds for the Central Universities (Nos. 2015B34614 
and 2015B14714), the Water Conservancy Science and Technology Project of Jiangsu (No. 2015087), and the Priority Academic Program Development of Jiangsu Higher Education Institutions. The authors extend their gratitude to the editor and anonymous reviewers for substantial comments on earlier versions of this paper.

\section{References}

1. YE Y.S., LIANG X.Q., CHEN Y.X., LIU J., GU J.T., GUO R., LI L. Alternate wetting and drying irrigation and controlled-release nitrogen fertilizer in late-season rice. Effects on dry matter accumulation, yield, water and nitrogen use. Field Crops Research. 144 (2013), 212, 2013.

2. SHAO G., WANG M., YU S., LIU N., XIAO M., YUAN M. Potential of Controlled Irrigation and Drainage for Reducing Nitrogen Emission from Rice Paddies in Southern China. Journal of Chemistry. 2015 (1), 1, 2015.

3. SUN H., ZHANG H., YU Z., WU J., JIANG P., YUAN X., SHI W. Combination system of full-scale constructed wetlands and wetland paddy fields to remove nitrogen and phosphorus from rural unregulated non-point sources. Environmental Geochemistry and Health. 35 (6), 801, 2013.

4. ZHENG S., XIAO M., MIAO Z. Nitrogen Losses in Paddy Field Drainage Modified by Different Water Level Regulations. Polish Journal of Environmental Studies. 26 (3), 1393, 2017

5. XIAO M., MIAO Z., LI Y. Changes of Root-Zone Soil Environmentin Flooded Paddy Field under Controlled Drainage Conditions. Polish Journal of Environmental Studies. 26 (2), 881, 2017.

6. XIAO M., YU S., SHE D., HU X., CHU L. Nitrogen and phosphorus loss and optimal drainage time of paddy field under controlled drainage condition. Arabian Journal of Geosciences. 8 (7), 4411, 2015.

7. XIAO M., YU S., CHENG G., SHAO D. Technical standards of irrigation and drainage management in paddy field of water-saving and pollution-reduction with high yield. Journal of Food Agriculture and Environment. 10 (2), 1005, 2012

8. WILLIAMS M.R., KING K.W., FAUSEY N.R. Drainage water management effects on tile discharge and water quality. Agricultural Water Management. 148 (2015), 43, 2015.

9. BONAITI G., BORIN M. Efficiency of controlled drainage and subirrigation in reducing nitrogen losses from agricultural fields. Agricultural Water Management. 98 (2), 343, 2010.

10. LU B., SHAO G., YU S.E., WU S., XIE X. The Effects of Controlled Drainage on N Concentration and Loss in Paddy Field. Journal of Chemistry. 2016 (1), 1, 2016.

11. WESSTRÖM I., MESSING I. Effects of controlled drainage on $\mathrm{N}$ and $\mathrm{P}$ losses and $\mathrm{N}$ dynamics in a loamy sand with spring crops. Agricultural Water Management. 87 (3), 229, 2007.

12. WANG J., WANG D., ZHANG G., WANG Y., WANG C., TENG Y., CHRISTIE P. Nitrogen and phosphorus leaching losses from intensively managed paddy fields with straw retention. Agricultural Water Management. 141 (2014), 66, 2014.

13. SHAO G.C., CUI J.T., YU S.E., LU B., BRIAN B.J., DING J.H., SHE D.L. Impacts of controlled irrigation and drainage on the yield and physiological attributes of rice. Agricultural Water Management. 149 (2015), 156, 2015.

14. LAMPAYAN R.M., SAMOY-PASCUAL K.C., SIBAYAN E.B., ELLA V.B., JAYAG O.P., CABANGON R.J., BOUMAN B.A.M. Effects of alternate wetting and drying (AWD) threshold level and plant seedling age on crop performance, water input, and water productivity of transplanted rice in Central Luzon, Philippines. Paddy and Water Environment. 13 (3), 215, 2015.

15. SHAO G.C., DENG S., LIU N., YU S.E., WANG M.H., SHE D.L. Effects of controlled irrigation and drainage on growth, grain yield and water use in paddy rice. European Journal of Agronomy. 53 (2014), 1, 2014.

16. TAN X.Z., SHAO D.G., LIU H.H., YANG F.S., XIAO C., YANG H.D. Effects of alternate wetting and drying irrigation on percolation and nitrogen leaching in paddy fields. Paddy and Water Environment. 11 (1-4), 381, 2013.

17. LEE C., FLETCHER T.D., SUN G. Nitrogen removal in constructed wetland systems. Engineering in Life Sciences. 9 (1), 11, 2009.

18. KIMA A.S., CHUNG W.G., WANG Y., TRAORÉ S. Evaluating water depths for high water productivity in irrigated lowland rice field by employing alternate wetting and drying technique under tropical climate conditions, Southern Taiwan. Paddy and Water Environment. 13 (4), 379, 2015.

19. LIANG X.Q., CHEN Y.X., NIE Z.Y., YE Y.S., LIU J., TIAN G.M., WANG G.H., TUONG T.P. Mitigation of nutrient losses via surface runoff from rice cropping systems with alternate wetting and drying irrigation and site-specific nutrient management practices. Environmental Science and Pollution Research. 20 (10), 6980, 2013.

20. YAO F.X., HUANG J.L., CUI K.H., NIE L.X., XIANG J., LIU X.J., WU W., CHEN M.X., PENG S.B. Agronomic performance of high-yielding rice variety grown under alternate wetting and drying irrigation. Field Crops Research. 126 (2012), 16, 2012.

21. LAMPAYAN R.M., REJESUS R.M., SINGLETON G.R., BOUMAN B.A.M. Adoption and economics of alternate wetting and drying water management for irrigated lowland rice. Field Crops Research. 170 (2015), 95, 2015.

22. YANG S., XU J., ZHANG J., WANG Y., PENG S. Reduction of Non-Point Source Pollution from Paddy Fields through Controlled Drainage in an Aquatic Vegetable WetlandEcological Ditch System. Irrigation and Drainage. 65 (5), 734, 2016.

23. PENG S.Z., YANG S.H., XU J.Z., LUO Y.F., HOU H.J. Nitrogen and phosphorus leaching losses from paddy fields with different water and nitrogen managements. Paddy and Water Environment. 9 (3), 333, 2011.

24. PENG S., YANG S., XU J., GAO H. Field experiments on greenhouse gas emissions and nitrogen and phosphorus losses from rice paddy with efficient irrigation and drainage management. Science China Technological Sciences. 54 (6), 1581, 2011.

25. de VRIES M.E., RODENBURG J., BADO B.V., SOW A., LEFFELAAR P.A., GILLER K.E. Rice production with less irrigation water is possible in a Sahelian environment. Field Crops Research. 116 (1-2), 154, 2010.

26. BOUMAN B.A.M. A conceptual framework for the improvement of crop water productivity at different spatial scales. Agricultural Systems. 93 (1-3), 43, 2007.

27. MOLDEN D., OWEIS T., STEDUTO P., BINDRABAN P., HANJRA M.A., KIJNE J. Improving agricultural water productivity: Between optimism and caution. Agricultural Water Management. 97 (4), 528, 2010. 
28. ZHAO X., ZHOU Y., MIN J., WANG S., SHI W., XING G. Nitrogen runoff dominates water nitrogen pollution from rice-wheat rotation in the Taihu Lake region of China. Agriculture, Ecosystems \& Environment. 156 (2012), 1, 2012.

29. GAO S.K., YU S.E., SHAO G.C., SHE D.L., WANG M., GUO R., CAO R.Z., YAN S.F., DING J.H. Effects of Controlled Irrigation and Drainage on Nitrogen and Phosphorus Concentrations in Paddy Water. Journal of Chemistry. 2016 (1), 1, 2016.

30. SHARPLEY A.N., MCDOWELL R.W., KLEINMAN P.J.A. Phosphorus loss from land to water: integrating agricultural and environmental management. Plant and Soil. 237 (2), 287, 2001.

31. MANZONI S., SCHIMEL J.P., PORPORATO A. Responses of soil microbial communities to water stress: Results from a meta-analysis. Ecology. 93 (4), 930, 2012.
32. YOSHINAGA I., MIURA A., HITOMI T., HAMADA K., SHIRATANI E. Runoff nitrogen from a large sized paddy field during a crop period. Agricultural Water Management. 87 (2), 217, 2007.

33. FRONCZYK J., SIECZKA A., LECH M., RADZIEMSKA M., LECHOWICZ Z. Transport of Nitrogen Compounds through Subsoils in Agricultural Areas: Column Tests. Polish Journal of Environmental Studies. 25 (4), 1505, 2016.

34. ZHANG Z.B., ZHOU H., ZHAO Q.G., LIN H., PENG $X$. Characteristics of cracks in two paddy soils and their impacts on preferential flow. Geoderma. 228-229 (1), 114, 2014.

35. TANG J., WANG T., ZHU B., ZHAO P., XIAO Y., WANG R. Tempo-spatial analysis of water quality in tributary bays of the Three Gorges Reservoir region (China). Environmental Science and Pollution Research. 22 (21), 16709, 2015. 